\title{
Appreciating Ashley: Learning About and From the Life and Death of Ashley Smith through Feminist Pedagogy
}

Joanne Minaker

\begin{abstract}
Feminist scholars and advocates struggle with how to confront the overcriminalization of the most marginalized girls and women. One of the most troubling illustrations of gross injustice is what happened to Ashley Smith. The anniversary of Ashley Smith's death is a catalyst for amplifying feminist voices. In this paper, I use the Ashley Smith case as a way to frame how I teach critical social justice issues concerning the criminalization of girls and women. My aim is to encourage critical conversations about pedagogy in feminist criminology and socio-legal studies aimed at ameliorative change. With the discipline of Criminology's systematic failure to understand the unique problems and shared circumstances of girls' and women's lives, feminist professors' teaching, which offers a lens for our students that underscores young women's constrained choices and the socio/ political/cultural context in which their lives and behaviours are embedded, opens up possibilities for transformation.
\end{abstract}

Keywords: social justice, criminalization, Ashley Smith, pedagogy, criminalized girls and women, feminist

\section{Résumé}

Les intellectuels féministes et les défenseurs des droits des femmes se butent à l'hyper-criminalisation des filles et des femmes les plus marginalisées. L'affaire Ashley Smith est un exemple d'injustice des plus troublantes. Le dixième anniversaire de son décès a eu un effet catalyseur sur la voix des féministes. Dans cet article, je recours à l'affaire Ashley Smith pour étayer mon enseignement des questions les plus importantes en matière de justice sociale, notamment à l'égard de la criminalisation des filles et des femmes. Mon but est de favoriser des échanges critiques au sujet de la pédagogie en criminologie féministe et en études sociojuridiques en ce qui a trait au changement amélioratif. Devant léchec retentissant de la criminologie à comprendre les problèmes uniques et les circonstances particulières vécus par ces femmes et ces filles, les enseignements de professeures féministes, qui offrent aux étudiants une approche soulignant les choix contraignants faits par les jeunes femmes et le contexte socio-politique et culturel dans lequel s'inscrivent leur vie et leurs comportements, créent de nouvelles possibilités de transformation.

Mots clés : justice sociale, criminalisation, Ashley Smith, pédagogie, filles et jeunes femmes criminalisées, féministe

Canadian Journal of Law and Society / Revue Canadienne Droit et Société, 2017, Volume 32, no. 2, pp. 291-306. doi:10.1017/cls.2017.15 


\section{Introduction}

"Yet only through communication can human life hold meaning" (Freire 1997, 58).

Feminist socio-legal scholars and social justice advocates are still wrestling with gendered injustices and struggling for meaningful change that will address the systemic failures of criminal justice and correctional responses to young women's crime and deviance. Put another way, we're collectively contesting the overcriminalization and hyper-confinement of women, girls, and trans persons, on legal, rights-based, moral, or ethical grounds. "Indeed, there is a problem when it comes to girls and crime. The real issue, however is not the girls themselves, but rather the injustices they face outside in the larger society-sexism, racism, poverty, etc. - and inside the YCJS - from denial of rights to violence and abuse to harsh paternalism" (Minaker and Hogeveen 2009, 114). One of the most troubling illustrations of gross injustice to occur through the criminalization of women is what happened to Ashley Smith. One significant implication of Smith's experience I explore in this paper is how we teach and learn from her governance and resistance. I see the tenth anniversary of Ashley Smith's tragic death as a catalyst for amplifying feminist conversations that challenge overt and subtle manifestations of patriarchy, androcentric discourses, and violence. One way to do this is through a feminist pedagogy, which can give meaning and significance to Smith. I take the case of Ashley Smith as a form of pedagogy based on an in-progress auto-ethnographic, experiential account of my own classroom teaching experiences.

Auto-ethnography is both a strategy and a process that allows me to reflect on my own pedagogy in a critical and political way. According to Sarah Stahlke Wall auto-ethnography "is an intriguing method that is increasingly utilized to study social phenomena through the lens of the author/researcher's personal experience" $(2016,1)$. Denzin $(2006,422-23)$ calls the approach a methodology that "listens to the heart," while Ellis and Bochner (2006) point to its transformative potential. My reflections on the transformative lessons we can learn about and from the life and death of Ashley Smith, draw on the insights of Paulo Freire's pedagogy of the oppressed and the work of Joanne Minaker and Bryan Hogeveen (2009) on social justice praxis. In this paper, I draw from first-hand experiences about and learning from the Ashley Smith case to show how critical pedagogy can operate as a form of social justice praxis. This framing enables students to think more critically and compassionately about how and why some people are Other(ed) in and through criminal justice and correctional systems. My aim is to meaningfully contribute to critical conversations about pedagogy, praxis, and possibilities for transformative social change.

In Pedagogy of the Oppressed, Paulo Freire positions the work of the revolutionary educator as coinciding "with those of the students to engage in critical thinking and the quest for humanization." These efforts are "imbued with a profound trust in people and their creative power" $(1997,56)$. From this perspective, recognizing the interplay of permanence and change as a condition of social structure, "dehumanization resulting from an unjust order is not a cause for despair but for hope, leading to the incessant pursuit of humanity denied by injustice" (72). 
My efforts are directed towards the "hopeful inquiry human beings pursue in the world, with the world, and with each other" of which Freire speaks. Criminology as a discipline still tends to overlook the unique problems and shared circumstances of girls' and women's lives, so it remains imperative that feminist professors offer a critical framing for their students that takes into account not just what young women do and how they are represented, but also interrogates their constrained choices and the socio-political and socio-cultural context in which their lives and behaviours are embedded. For almost ten years in the context of the post-secondary classroom, namely in a Youth, Crime and Society course and a Gender, Crime, and Social Justice seminar, I have spoken about the tragic life and death of Ashley Smith. I am deeply concerned with Smith's right to be treated as fully human and seen as a human being versus an object to be examined and governed.

The paper is organized as follows. First, I call for problematizing dominant narratives and socio-cultural constructions that constitute the female offender as "Other" in order to move beyond popular representations of Ashley Smith. Second, I explore what a re-framing of Smith's story might look like if the goal of the feminist criminologist's teaching is to humanize. Next, I illustrate how Ashley Smith's story informs how I teach critical social justice for criminalized girls and women. I present an auto-ethnographic account that describes and reflects on the ways I communicate with my students about Ashley Smith, employing themes for understanding criminalized girls (what I call "the 6Rs"), illustrates how these engagements play out in the classroom, and explores the implications for social justice. Post-secondary students, especially those studying criminology, criminal justice, law, and social work, (enter and) exit college and university classes with not only a set of knowledge claims about the nature and extent of female crime, but also ideas about "who" the women who occupy the marginal positions of criminal, prisoner, victim, and/or deviant girl are. They will bring the perspectives they develop (as informed by our pedagogy) into their lives as community members and, potentially, their roles as criminal justice professionals and/or state employees in the correctional system. Following Freire, I remain hopeful that students may leave our classrooms with a deeper awareness of their own place in the world and a greater willingness to act in a transformative way upon it.

\section{The Personal is Always Political, Still}

From the normative misogyny embedded in our everyday encounters to horrific and egregious harms inflicted against girls and women, gender-based oppression continues, even for privileged women. From the way prominent male politicians routinely shame female leaders and slander their name and objectify them as their appearance, to rape myths that men in powerful positions (like judges) espouse, from victim blaming to survivor shaming or the reduction of rape culture to "locker room talk," and the sexual harassment, abuse, and violence women continue to face, the personal is always political. Far too many examples inside and outside the correctional system demonstrate the need to present a feminist informed perspective to our students, which understands the criminalization of women as linked to the cultural constructions of constrained femininity and hegemonic masculinity and 
structural positioning along intersectional hierarchies of gender, race, class, and other dividing lines of difference and inequality (Balfour and Comack 2015). If a powerful white male leader can attack on a public stage one of the most powerful (white, heterosexual, abled-bodied) women in the world (i.e., US Secretary of State and 2016 presidential candidate, Hillary Clinton), then imagine the gendered injustices that go unchecked for marginalized girls like Ashley Smith.

As a white, cis gendered, married, mother and University professor, I am afforded considerable privilege to speak and be heard. Yet, one of the key dilemmas I/we continue to confront is gaining (and keeping) the status of, in Laureen Snider's $(2015,270)$ terms, "authorized knower," to be taken seriously when constructing counter-narratives that contest the misogyny, misunderstandings, and malevolent practices endemic to the criminalization of girls and women. As Snider reminds us, "While we cannot control how our arguments are heard, or predict their consequences, we can make our messages harder to mishear" $(2015,270)$. Here is a case in point for the need to magnify feminist analyses: I recently showed a video in my criminology class about the manhood mandate and its relationship to male violence and crime. The speaker in the video was a white, older man, a former athlete and professional coach. His message - that in North America, boys and men are socialized to accept and adopt the view that being a man and performing masculinity requires exerting power and control-was compelling, though his explanation for "why" this occurs was not feminist nor sociological. I asked the students if his gender status (among other markers of privilege) made what he had to say more convincing. Many students seemed to agree that it did. One student offered that compared to hearing this message about masculinity from me, having a man make this claim was more powerful because, "he's been there." If by "there" the student meant having lived as a man, then, the point is well taken. However, I begin to take issue when we extend "been there" to having experienced, witnessed, or otherwise been impacted by misogyny and hegemonic normative assumptions about my (or any female's) capacity for agency, autonomy, and authority. Like many readers, I do not have to refer back to my history of 'growing up girl' (which invariably for most of us involves experiences of abuse or violence at the hands of men and patriarchal institutions) to recall when I was put in my place because I am female. Sexism in the university setting continues, despite the power and privilege academic women have achieved. Our gendered experiences are unique, racialized, and class compounded; while in so many ways our lives and experiences as feminist scholars who write in journals like this one are nothing like those of the women behind bars we write about, in other ways, sadly, they still are. Being a professor socialized into feminism and the pursuit of knowledge for socially just transformations, I hold onto hope that post-secondary institutions can be spaces of resistance, and take up the classroom as a place to explore the production of meaning.

As someone who identifies with Feminist Criminology, it is important that I demonstrate for my students what doing criminology from a feminist perspective could look like. Like my colleagues who have led the way by sharing their ideas about Ashley Smith's criminalization (Bromwich and Kilty, this volume), I recognize that for Smith's life and death to not be in vain, we owe ourselves, our discipline, 
and we owe it to Ashley Smith, to learn something important from her story. Among the 104 recommendations made to the Correctional Service of Canada, the 2013 jury contended that the Ashley Smith case should be used as a "case study" for correctional reform. No matter the angle from which one looks at Ashley Smith's encounters with Canada's criminal and correctional justice systems-be it from a legal, political, moral, and/or social dimension(s)—undoubtedly, we see grave concerns about her treatment. That the 2013 verdict of the coroner's inquiry, for the first time in Canadian history, declared Smith's death a homicide does not imply systems have been held accountable.

This all raises a host of questions about law, society, and care/control: What knowledge claims inform a feminist understanding of what happened to Smith? How do feminist scholars studying and teaching courses on gender and justice articulate the Ashley Smith case to students? What responsibilities do we have when we study social issues in terms of political engagement? Using Freire's language, in what ways can or do we connect critical reflection with critical action? These questions still perplex me and this paper does not set out to present empirical findings to resolve these issues. Rather, in what follows, I share the conceptual tools and teaching strategies that I have found useful for fostering students' critical thinking in a way that inspires them to appreciate Ashley Smith (and all criminalized girls and women) as more than a case. That is, to recognize that Ashley Smith's encounters with the Canadian criminal justice system (CJS) and Correctional Service of Canada (CSC) deserve our attention because she was a young woman in her process of becoming denied dignity and humane regard.

\section{Communicating Ashley Smith's Story through Feminist Pedagogy}

Feminist criminology shifts attention away from the discourse of the "criminal girl/woman" to critically examine discourses of criminalized girls/women. Feminist professors participate in the production of meaning when we (re)create the discourses that give meaning to Ashley's story. Back in 2008 when I began to bring Ashley into class discussions, it was rare for students to recognize her name or know anything about her story. One decade later, much has changed. Multiple hands go up when I inquire who has heard about the Ashley Smith case. While more students know her name, they do not necessarily understand why she matters. Even if they think they know her, presumably most do not know how to deconstruct what happened to her. I argue that Ashley Smith's story is simultaneously typical and atypical, showing both how similar and how unique she was compared with most criminalized young women. I recall having five out of forty students one year with the name Ashley, and the commonness of "Smith" as a North American surname almost goes without saying.

During class, as quickly as I utter her name in a lecture, students can enter "Ashley Smith" in a general Google search and the first search hit to appear is the Ashley Smith inquest page on Wikipedia, which offers a popular representation of her case: “The Ashley Smith inquest was an Ontario coroner's inquest into the death of Ashley Smith, a teenager who died by self-inflicted strangulation on 19 October 2007 while under suicide watch in custody at the Grand Valley Institution for Women" (Wikipedia). The description- "Ashley Smith, a teenager 
who died by self-inflicted strangulation"-acts as a buffer that decontextualizes and dehumanizes Smith's suffering, which effectively distances students from the individual at the heart of this disaster and the broader structural issues at work. Her death here is un-problematically called "self-inflicted." The popular framing reinforces Ashley Smith as an object of governance and study, rather than a moral subject and agent. Our task, as feminist professors, is to help students critically unpack what happened, raise questions of accountability, and analyze different events that led to her death. That is, to reveal what is exceptional about her experience and also what systemic processes are at work that require constant interrogation (and activism). "Died by" at once attributes culpability to her and relinquishes her humanity. We may never fully appreciate Ashley for who she was in all her agency and vulnerability. However, to see her struggles and her strengths, and her entanglements with criminal justice and correctional systems as, in part, creating her troubles challenges the narrative that Smith was a deviant girl, who was either "troubled" and in need of help and treatment, or "trouble" and required disciplinary punishment and solitary confinement. Ashley Smith's experiences continually demonstrate that she was cast as an "Other," undeserving of recognition, positive attention, and caring social relations. My goal of students coming to "appreciate" Ashley Smith as a human being makes it possible that they extend this empathetic lens to other criminalized girls. To do this, I encourage them to develop their own gender-sensitive understanding of criminalized girls as girls. That is, "to put young women's lives, experiences and behaviours in a socio-cultural and political context, one largely structured by privilege or inequality along race, class, and gender lines" (Minaker and Hogeveen 2009, 125).

One way to challenge a dehumanizing reading of Smith's case is through problematizing stereotypes. According to Hall, a stereotype "facilitates the 'binding' or bonding together of all of Us who are 'normal' into one 'imagined community'; and it sends into symbolic exile all of Them-'the Others' - who are in some way different-'beyond the pale.' Mary Douglas (1966), for example, argued that whatever is 'out of place' is considered as polluted, dangerous, taboo" (258). Also instructive is Hall's conception of how the spectacle of the Other operates as the "power in representation; power to mark, assign and classify; of symbolic power" (258). As we shall see, I involve my students in classroom activities that illustrate the power in representation. They come to recognize how each different actorfrom correctional officials to independent government agents or the media and academics - presents a different "take" on representing Ashley Smith. Attending to this understanding of power in wider cultural and symbolic terms helps students to appreciate their own agency in how they come to represent someone, namely Ashley Smith, in a certain way and the consequences of the representations they rely on to frame their accounts of her behaviour, mistreatment, and death.

Feminist criminologists have demonstrated how Ashley was constituted as Other-by both Correctional Service of Canada, which constituted her as a dangerous girl and misbehaving prisoner, and by academics, feminist criminologists in particular, as a victim of the state (Kilty 2015; Bromwich 2015). I attempt herein to move beyond these constructions, by encouraging us to see Ashley Smith as a vulnerable actor within the complex of psy-correctional-risk discourses that governed 
how she was treated/managed through state actors-all while she was literally becoming or growing up. Animating and engaging with this more nuanced and lively rendering of the events that unfolded from Ashley's first conflict with the law as a teenager to her untimely death in a women's federal prison enables me to simultaneously teach and learn about and from her life and death. It is important to provide space and opportunity for students to engage in their own critical theorizing and possibly activism around issues that are important to feminist criminological efforts. One way to "do" social justice in the classroom is to encourage students to challenge ideas and actions, so that they become better able to think through how injustices affect everyone, not just some at the margins. "Critical reflection," Freire argued, "is also action" (109).

Ashley Smith's life and death reveal the problematic ways that social institutions continue to reinforce and reproduce conditions that marginalize young women who act against cultural scripts of good or appropriate femininity (Minaker and Hogeveen 2009; Kilty 2015). Moreover, her experiences with youth and adult corrections demonstrate how our criminal justice and correctional systems penalize "bad" girls and mete out gendered consequences for their disorderly conduct and defiance. While mental illness, for example, was part of Ashley's story, a reading of her story through a lens of "the mentally ill girl" narrowly renders her un-problematically as an object of psy care/treatment, but not a subject. A feminist reading challenges students to imagine treating girls who resist normative or misogynist gendered expectations with respect and care, with dignity as human beings.

The ways we communicate about Ashley Smith's life and death have implications for how we account for what happened to her-do we document a story of institutional failures and omissions or do we reveal through critical pedagogy a complex human story of lived experience and traumatic loss of life? The accounts we socially construct may have the power to chip away, changing and challenging systems of oppression and injustice. The categories and groups to which we (as models of feminist criminology) assign Ashley Smith-offender, girl, youth, daughter, prisoner, patient, victim, etc._-impact how we see her, given that our "making sense of things" occurs through placing her discursively into wider social categories (Hall 2012). I try to avoid a static approach that seeks to determine lessons learned (past tense) from the case of Ashley Smith, which has the danger of presenting a narrative of what should be taken from the case. Alternatively, I offer a more active, dynamic and relational approach to the teaching and learning process, striving to "open up" dialogue with students regarding the possibilities about what could be changed, how we can challenge current oppressive systems, and our potential to create more just and caring communities. This approach aims to humanize rather than objectify Ashley Smith as a subject of correctional care, mistreatment, and resistance. Can students "appreciate" Ashley Smith's life (and the meaning of her death) beyond her representation as a "case" of a mentally ill prisoner or criminal girl or correctional oversights? Reinforcing a dehumanizing account of her story has consequences, especially for the young women who journey in her footsteps. Rather, my experience reveals how students can and do develop a different, more critical and compassionate understanding of the criminalization of girls and women. Below I will show how students come to "appreciate" Ashley Smith as 
a complex, relational, human being with needs, desires, dreams, aspirations, and agency. As one student put it, "a case is something to be studied; a person is someone to be appreciated."

\section{Social Justice Praxis in Action: The 6Rs}

Ashley's story illustrates the challenges girls face both in and outside of the criminal justice system and as they attempt to carve out their own paths and write their own life stories. In this section I demonstrate how a social justice praxis (SJP) approach frames my teaching and students' learning about marginalized populations, and specifically this case. In communicating with the praxis approach, I situate the criminalization of women and girls along a continuum of institutional sites, which broadens the conversation to one of social, not criminal, justice. This works to problematize the extent to which various systems (e.g., family, school, youth detention, women's prisons) have the effect of marginalizing (i.e., excluding or closing down possibilities) and/or empowering (i.e., increasing control and agency or opening up possibility). Like Freire's Pedagogy of the Oppressed, SJP moves beyond the teacher depositing narrated content into the student container. Rather, resisting the model of teacher as depositor and students as depositories, SJP allows students and teachers alike to simultaneously attempt to understand in/justice and explore possibilities for just social transformations. Social justice praxis involves two components: 1) critical reflection and 2) social engagement (Minaker and Hogeveen 2009). To explore possibilities for SJP here, I intersperse my approach and students' writing about their engagement in the process. I draw on input from one student in particular whom I solicited over one year after she studied in my Gender, Crime and Social Justice seminar as well as several student responses to a learning exercise from winter 2017 Youth, Crime and Society course.

As a starting point for our discussion, I share a short excerpt about the Ashley Smith case or show a short video, then explain the purpose of the class. After this brief introduction, I pause and give students an opportunity to put in their own words what I have been talking about. I ask them to rephrase what they think it means "to appreciate Ashley." These thoughtful responses show how keenly aware they were of our learning objective when our task was framed in this way. Appreciating Ashley is ... (Anonymous students 2017)

To see her as a person, not as a "criminal," but a complex human with feelings and fears

To look at how things went wrong for Ashley

To question how CJS/CCC treats women and girls and evaluate current practices

To question and observe the hidden gender bias built with YCJS and society as a whole

To open up and see her not as an object

To humanize not just Ashley Smith but all women who are treated unfairly

I thread individual and group activities intended to stimulate critical, sociological thinking into a lecture called "Individual-level and Structural-level Pathways" on girls' criminalization. Group participation involves a series of questions and activities. 
First, I ask: What categories or groups can we assign Ashley into? Brainstorming reveals deviant and non-deviant labels, such as young offender, mentally ill, angry, young woman, neglected, criminalized, dangerous, uncontrollable, misunderstood, isolated, lonely, suicidal, bad girl, victim, damaged, patient, prisoner, daughter, behaviourally problematic. Second, I read portions of media representations from prominent Canadian newspapers and ask students to think about how Ashley is represented in these popular narratives; the degree to which she becomes an object or a subject.

Next, I provide a conceptual framework to students, which I refer to as the 6R's-root, risk, range, relationships, response, and respect. In class we engage together with these six key constructs for appreciating the circumstances that Ashley faced before and during her incarceration, which allows us to make sense of how she met the tragic fate she did. For example, during my winter 2017 classes, I did the 6Rs exercise and then students worked in pairs to unpack the categories and identify their assumptions.

I had a unique occasion while writing this paper to ask a former student from my Gender, Crime and Social Justice 2016 seminar about the lessons she took away from our discussions about Ashley Smith. After seeing her at a university event, I emailed her a simple request to share any lasting lessons from learning about Ashley Smith. She responded almost immediately: "I definitely remember learning about Ashley Smith in your class and I found it to be one of the most striking examples used" (A.S. 2016). In what follows, I explain these key learning tools (the 6 Rs) and illustrate each of them by beginning with a quotation (with permission) from the student perspective to demonstrate the possibilities of both SJP and treating Ashley Smith's case as a form of pedagogy. Interestingly, the student's initials are also A.S.

\section{ROOT}

"When you think of the Criminal Justice System, you think of law and order, you think of the protection of society for the good of society, and the safety and rehabilitation of incarcerated persons; what is realized in the Ashley Smith case is that both the CJS and CSC doesn't always follow its own fundamental values." (A.S. 2016)

The construct called root refers to systemic, structural factors. Pointing to the root, we consider the macro concerns and forces that shape social, cultural, and political life (e.g., patriarchy, economic inequalities, and racism). Structural level issues involve social hierarchies around gender, race, class, etc. that perpetuate and sustain inequalities, which dramatically impact girls' and women's lives. These include, but are not limited to, gendered violence, poverty, school disengagement, and family conflicts. Students are often able to identify how many of these factors were present (though not problematized) in popular accounts of Ashley Smith's life. For example, "I see how systems mistreated Ashley," wrote one student, pointing to core hierarchies that perpetuate inequality and injustice. Another one commented that looking at the root "reveals gendered consequences of deviating from sociocultural scripts and being 'a girl' in the social world where gender powerfully shapes our experiences." Examining the root involves discussing systemic issues 
that are raised by Ashley Smith's treatment outside and inside Corrections Canada and the Youth Justice System. By calling attention to the way gender and girlhood get represented in popular culture, students begin to realize that the "unfinished character of human beings and the transformational character of reality necessitate that education be an on going activity" (Freire 1997, 65). This movement, for Freire, begins with human-world relationship. By working with my students and their working together we become "[s]ubjects of the educational process by overcoming authoritarianism and an alienating intellectualism" (67).

\section{RISK}

"Ashley Smith was viewed as an 'Other,' different from other girls." (A.S. 2016)

Risk appears where structural issues (the macro) are made real at the experiential level of interaction and identity (the micro). Risk is an important concept to unpack, especially when powerful discourses of risk are deployed to "responsibilize" the individual, which does not locate girls' troubles within social problems that condition and contour their experienced "risk factors" in their own lives. When political issues are personalized and the effects of injustice are shouldered at the individual level, risk discourse moves into the realm of risk assessment, prediction, and management. As I explain in class, if gendered violence is the root, then, risk is a young woman's lived experiences of abuse, sexual abuse, or violence; these are inexorably linked. This inquiry draws attention to the individual and interpersonal level. Here we discuss categories used with criminalized girls like "risky" or "at-risk" or "highrisk," and how dangerousness is socially constructed. The individual-level effects of systemic inequalities and "risk governance" in Ashley Smith's case give meaning to things like self-harm and mental health distress, as they relate to questions of identity. Rebecca Bromwich (2015) analyzes how the way the Ashley Smith case is variously represented leaves intact, and even reinforces, logics and systems that govern gender, security, risk, and exclusion. In short, a dominant paradigm constructed Ashley Smith as "the dangerous other" (even as the main target of any harm was usually herself). While Smith did place a ligature around her neck on October 19 2007, we cannot presume that she intended to die. Students grapple with tough questions about responsibility and accountability, which makes for at times uncomfortable silences and difficulties for me navigating between imparting my own ethic and providing a forum for students to discuss and debate. Many practice empathy, asking: what might it be like to be in Ashley's position, or to play the role of the guard acting under orders of supervisors?

\section{RELATIONSHIPS}

"In terms of relationships and interpersonal value in the context of Ashley Smith, a huge difference in outcome, both for herself and others, could be different if anyone had taken the time to connect. From Ashley's story, we learned about the troubled history she had and we think, 'Oh, how did it get to this point?', but we also have to ask if there had been an attempt to make a human connection with Ashley instead of using punitive measures, would there have been a basis for punitive measures to be used at all?" (A.S. 2016)

This construct comes as no surprise to my students, as they learn early in the course the power of meaningful connections for youth. Relationships are essential 
for everyone. Examining the relational level means focusing on human connections. It's asking, "Who was there for Ashley Smith?" Valuing relationships implies other values related to interpersonal treatment. Here, I'm thinking of Alison Liebling's (2011) work on the im/moral performance of the prison, where she considers six key factors: respect, humanity, fairness, order, safety, and staff-prisoner relationships. We can ask: To what extent are imprisoned women, like Ashley Smith, provided with opportunities to form meaningful relationships, as was recommended in Creating Choices? In Smith's circumstances, and similarly for others locked up in segregation, when constituted as 'risky' or governed under the Correctional Service of Canada Management Protocol, space for authentic human connection is extremely limited. Meaningful connection gives human lives significance and purpose; without it we are vulnerable to hopelessness and despair.

\section{RANGE}

"Another thing that I took away from your teachings, is that every single person is unique, and that the label 'criminal' does not frame the entirety and [does not] see intersecting social locations." (A.S. 2016)

Range is about the heterogeneous experiences and social locations from which girls live. I encourage students to consider how root and risk relate to the power/ authority that affect girls' autonomy, voice, and choice. If range means the diversity and divergence between and across young women's lives, then questions arise concerning the degree to which systems address girls' unique perspectives and positionality. Intersectionality illuminates how social relations imbued with gender, race, class, age, sexuality and other power dynamics impact girls' lives. What different ways do girls cope with their struggles? How do girls respond to and make sense of their diverse experiences? Given that there are many different social institutions and people are criminalized in different places to varying degrees, Ashley Smith's experiences are not representative of all criminalized girls. Through intersectional analyses we are looking for how cultural and material realities of gender, race, class, and age are at work. Students usually acknowledge that Ashley Smith's social location and racial group is at odds with their perceptions of who is most likely criminalized.

\section{RESPONSE}

"This really brought to my attention what empowerment could have done for Ashley, within an appropriate mental health setting, not a criminal one. If she had the ability to be able to speak about the issues she was having instead of needing to cry out for help through what guards and staff considered a nuisance, I think that Ashley would still be here today and in a much better state of mind. Her problems were not minimized through the CJS, they were maximized. There was no rehab, there was punishment." (A.S. 2016)

Central to our inquiry is how girls are treated. Response, then, refers to institutional and interpersonal responses to young women. How do various social systems respond and react to girls' behaviours, conflicts, and problems? This involves key sites of criminal justice, including the youth justice system (YJS) and CJS and CCC, but also the girls' communities. How do our social, educational, and legal institutions respond to girls' deviance, their troubles? Ashley Smith's experiences 
with provincial and federal correctional systems are telling in this regard. What would be considered minor infractions outside in the community became a long list of crimes inside, which institutional authorities responded to by continuously upping the ante of punishment. This is what happens when youth suffering from mental illness and severe behavioural disorders are sent to jail. This is what happens with adulteration. Susan A. Reid and Sarah Gilliss define adulteration as "the dismantling of a distinct system of criminal justice for youth and the re-merging with systems of justice for adults" $(2015,124)$ and argue it was clearly done in Ashley Smith's case. The institutional failures, oversight, and ultimate responsibility of CSC for her death require problematization. According to Article 40 of the 1992 UN Convention on the Rights of the Child, those who violate the law are to be treated in a manner consistent with the desirability of promoting the child's (re) integration into society and taking up a constructive role.

In our discussions, students often ask what programming, resources, services and supports were available to Ashley Smith within the federal system she was transferred to. One key rationale for imposing adult penalties and involving Smith in the federal adult system was for the additional supports she would access therein. According to Reid and Gilliss $(2015,125)$, "With the promise of more gendersensitive programming and mental health treatment offered through the Correctional Service of Canada, the provincial (Nova Scotia) direction made an application under section 92 of the YCJA [(Youth Criminal Justice Act)] to transfer Ashley Smith to the adult system. During the one year she was housed in the federal system, she spent all of her time in administrative segregation and was transferred seventeen times between three federal penitentiaries, two treatment facilities, two external hospitals, and one provincial correctional facility in four different provinces." One student told me, "I wish they handled this more compassionately."

\section{RESPECT}

"This really taught me that we have to consider all people in the CJS as people, real human beings. It's easy to not care about someone once they get a guilty verdict." (A.S. 2016)

Respect is a practice, demonstrated through appreciating another's humanity by acknowledging that their voice matters (listening), recognizing their life has value (seeing them as human), and extending care and concern towards another person (treating them as worthy of love and belonging and with dignity). Ashley Smith was routinely subjected to humiliating and degrading treatment; she was denied the right to health care, denied freedoms and basic dignity, and-against the 1992 UN Convention on the Rights of the Child-deemed unfit for social interaction. Why was Smith locked up in the first place? We know her early conflicts with the law comprised minor infractions like stealing a CD and throwing crabapples at a postal worker, which begs the question: Were other systems better suited to respond to (care for?) her needs? Why did her behaviour warrant incarceration? Ashley Smith came to prison as a non-conforming, deviant girl, and she was discursively reconstituted as a dangerous, mentally ill girl. What gets missed is how corrections and criminal justice discourses and practices contributed to that remaking (i.e., solitary confinement, withholding proper mental health care, 
disregard for her own story) or to her resistant behaviour and/or exacerbated her mental health concerns. To appreciate Ashley Smith as a human being is to recognize her agency, autonomy, and voice, while simultaneously recognizing the constraints and controls that ultimately led to silencing and destroying her.

Critical thinking questions are important pedagogical moments for exploring what meaningful change could look like. To create openings for social engagement outside of class, I foster student participation in class by a variety of exercises that stimulate both cognitive and emotive understanding, have students work both independently and together, as well as utilize a variety of mediums (e.g., Power Point slides, handouts, wipe board brainstorming, five-minute paper writing, etc.). My hope is to engage students to become more curious about both what happened to Ashley Smith, why, and what else is possible for other young women walking similar paths.

Rather than present a lecture built on an argument of what actions we can or we should take up, I lead a dialogue about what else is possible. This inquiry suggests a reframing of Ashley Smith as a young woman struggling in her process of becoming, just like so many other girls (and marginalized boys) do. She, like other girls, encountered various systems with varying degrees of potential to open up or close down possibilities for her being and becoming. "People, as beings 'in a situation, find themselves rooted in temporal-spatial conditions," Freire writes, conditions "which mark them and they also mark. They will tend to reflect upon their 'situationality' to the extent that they are challenged by it to act upon it. Human beings are because they are in a situation" $(1997,90)$. In Freire's words, "problemposing education affirms men and women as beings in the process of becoming" (65). As Ashley Smith left adolescence and entered young adulthood while incarcerated in a women's prison, she behaved in ways that ran counter to institutional rules and social conventions of femininity. She spoke out. She didn't listen to authority. She questioned adults. She was hurt. She hurt herself. The discourse of the dangerous prisoner employed to justify punitive practices used against Smith to bring about compliance and conformity ignores her suffering. Her need for human connection, love, acceptance, belonging, and kindness were overlooked by correctional demands for order, control, security, and power. As students come to realize their own agency in learning and acting in the world, they participate in the transformative education for which Freire calls. As he articulated, "Education is thus constantly remade in the praxis. In order to be (education), it must become" (65).

As this paper has shown, still ten years later, Ashley's life and death raise several important questions to examine beyond academia. For example: How can we better care for women struggling with mental health? What are ways to challenge dominant psy-correctional disciplinary risk logic that views self-injurious behaviour committed by women as security threats? Ashley Smith's case exposes the oppressive gendered carceral realities women face. A feminist pedagogy offers a way for students to see the psycho-social and structural constraints upon women's choices which makes it more difficult for them to reify the crime category of "offender" and easier to empathize with the plight of young women like Ashley. This piece is a call for feminist scholars to reflect upon how "Ashley Smith" gets taken up in university classrooms. This involves reflecting upon the feminist 
narratives that are being constructed. We can engage in reflexivity, asking: What makes my reading/teaching feminist? In taking the Ashley Smith case as a form of pedagogy and showcasing unique aspects of my teaching process and promising student learning outcomes, I hope I have offered new ways to appreciate Ashley Smith and criminalized girls. We may not be able to resolve systemic issues through pedagogy, yet we can persist in our critical reflections and in our social engagement-and thereby model social justice praxis to, for, and with our students.

\section{Conclusion: Towards Transformation}

"Through your class, I think we were definitely able to start doing this ourselves [critical reflection to appreciate Ashley] and examine how these things relate to a person's choices. The conversation is not easy. It requires being vulnerable, but it was also extremely valuable." (A.S. 2016)

"Revolutionary praxis must stand opposed to the praxis of the dominant elites, for they are by nature antithetical." (Freire 1997, 107)

Freire reminds us that teaching has a fundamentally narrative and revolutionary character. Rather than fill students up with their own narration, I challenge feminist teachers to communicate with our students-especially about tragic injustices like Ashley Smith's story-to develop critical consciousness that they may take with them as change agents, transforming the discourses and practices that perpetuate systemic oppression and violence. This is really about critically reflecting on their/ our/her own experience and also critically acting on it.

A rewarding experience to coincide with writing this paper was marking midterm examinations where students were able to identify and explain these constructs for understanding criminalized girls and poignantly articulate their own claims about possibilities for justice. I read paper after paper where students wrote about Ashley Smith in a kind and understanding way, not as an "Other." Until more is done inside and outside prisons to acknowledge and alter the social conditions that contribute to the maintenance of women's and girls' confinement, we will continue to confront the questions and concerns raised by Ashley Smith's carceral experiences. Yet, feminist professors-through our pedagogy-can offer students a lens that underscores young women's constrained choices and the socio-political and cultural context in which lives are embedded, thereby opening possibilities for social transformation. Systems outside corrections and criminal justice systems have far greater potential to foster hope and healing than sites of repression/oppression ever can. Community supports-from education to work, from treatment to counselling-are integral to better addressing mental health issues criminalized girls and women face.

This paper is also an invitation to engage in more feminist, qualitative research which aims to listen to the stories of the girls themselves-learning from them before it is too late. This challenge presents an opportunity. Correctional Service Canada's history of denying access to researchers notwithstanding, we can make space for knowing and sharing girls and women's stories by developing creative ways to collaborate with allies in agencies working with marginalized women, making 
community-university partnerships, and through creative work with our students involving community service learning or community-based research projects. Two potential lines of inquiry that re-emerge in my classrooms are: 1) To what extent do young women feel cared for, empowered, and/or marginalized in their encounters with systems that purport to help them and in their interactions with professionals charged with their care and/or control? 2) How do their experiences differ across the sites (i.e., health care, education system, child welfare, youth justice, criminal justice system), the professionals (e.g., teachers, nurses, youth workers, doctors, correctional workers, etc.), and across social identities (e.g., race, class, sexuality, age, and gender)? Conversations about alternatives to custody and the western fascination with punitive justice are beyond the scope of this paper.

Ashley Smith was not only a prisoner or victim of homicide. Ashley was not a character in a movie playing the "mad," "sad," and/or "bad" girl. She was a person with potential and dreams. When my daughter was three years old, she'd say, "When I grow up I want to be a princess and a firefighter" (though she pronounced it fighter-fighter at the time). Now, almost seven, she confidently asserts, "I am going to be a chef." She is early along in her process of becoming, though beginning to carve out her own identity as a girl, establishing peer networks within a culture of feminine/masculine limits, and gaining some acceptance within those cultures from a place of secure attachment and attentive care. I wonder what Ashley Smith's childhood dreams were. I have every reason to believe her mother loved and cared about her little girl very much. I wonder if she felt any peace before leaving this earth. Did she ever get to know and appreciate who she was as a person not a prisoner?

One of the saddest parts of Ashley Smith's story, as Rebecca Bromwich (2015) reminds us, is that the person Smith hurt was primarily herself. Her death is a loss of her human potential. A.S. (my student) put this so poignantly when she said, "Ashley's life has sadly been remembered because of her death. How incredible would it have been for her to be with us today in proper, or maybe even out of proper, treatment, with goals, visions and experiences that we all take for granted." In the end, she paid the ultimate price for betraying social norms. While practices of othering sustain a gendered social order within the contradictions of contemporary girl culture, our challenge is to provide spaces to support all girls so that young women can appreciate the fullness of their humanity. Otherness may still be at work, lingering in our narratives. As Hall would suggest, "rather than a 'right' or 'wrong' meaning, what we need to ask is, which of the many meanings in this telling of Ashley's story is privileged?" When Ashley Smith becomes $\mathrm{x}$, she is turned into what and for what end? We can continually ask: What does this message or image ignore and obscure? Where is our story anchored? In whose interest is it to keep some narratives out of mainstream media, dominant institutional discourses, and political discussions? Criminal justice and correctional spaces are not ideal settings from which to address the struggles so many girls and women are forced to endure; the bigger challenge involves counter-hegemonic cultural and societal transformations. A.S. articulated what Ashley Smith cannot say: "Difficult conversations have to be had, organizational culture has to be challenged, and individual perceptions have to be changed" (2016). Ashley Smith had very little power to 
constitute herself, to define or classify what she was or was not. All girls and women are deserving of concern, dignity, and care. Regrettably, so many young women, especially those marginalized racially or economically, are unseen, unheard, and unappreciated. In our ongoing communication and resistance, we give meaning and significance to them. And, we appreciate Ashley Smith.

\section{References}

A.S. anonymous student. Winter 2016. Soci-430 Gender, Crime and Social Justice. MacEwan University.

Anonymous Students. Winter 2017. Soci-321. Youth, Crime and Society. MacEwan University. Balfour, Gillian, and Elizabeth Comack, eds. 2015. Criminalizing Women: Gender and (In)Justice in Neo-Liberal Times, $2^{\text {nd }}$ ed. Halifax: Fernwood.

Bromwich, Rebecca. 2015. Looking for Ashley: Re-Reading What the Smith Case Reveals about the Governance of Girls, Mothers and Families. Bradford: Demeter Press.

Denzin, Norman K. 2006. Analytic autoethnography, or Déjà Vu all over again. Journal of Contemporary Ethnography 35 (4): 419-28.

Ellis, C., and A. Bochner. 2006. Analysing Analytical Autoethnography: An autopsy. Journal of Contemporary Ethnography 35 (4): 429-49.

Hall, Stuart. 2012. Representation: Cultural Representations and Signifying Practices. London: Sage.

Freire, Paulo. 1997. Pedagogy of the Oppressed. New York: Continuum.

Kilty, Jennifer. 2015. Examining the "Psy-Carceral Complex" in the Death of Ashley Smith. In Criminalizing Women: Gender and (In)Justice in Neo-Liberal Times, $2^{\text {nd }}$ edition, ed. Gillian Balfour and Elizabeth Comack. Halifax: Fernwood.

Liebling, Alison. 2011. Moral Performance, Inhuman Treatment and Degrading Treatment and Prison Pain. Punishment in Society 13 (5): 530-50.

Minaker, Joanne, and Bryan Hogeveen. 2009. Youth, Crime and Society: Issues of Power and Justice. Toronto: Pearson Education Canada.

Snider, Laureen. 2015. Making Change in Neo-liberal Times. In Criminalizing Women: Gender and (In)Justice in Neo-Liberal Times, $2^{\text {nd }}$ edition, ed. Gillian Balfour and Elizabeth Comack. Halifax: Fernwood.

Reid, Susan A., and Sarah Gilliss. 2016. Key Challenges in Hearing the Voice of Youth in the Youth Justice System. In Youth at Risk and Youth Justice, $2^{\text {nd }}$ edition, ed. John Winterdyck and Russell Smandych. Don Mills: Oxford University Press.

Wall, Sarah Stahlke. 2016. Toward a Moderate Autoethnography. International Journal of Qualitative Methods January-December: 1-9.

Wikipedia contributors. Ashley Smith inquest. Wikipedia, The Free Encyclopedia. https:// en.wikipedia.org/wiki/Ashley_Smith_inquest.

Joanne Minaker

Associate Professor

MacEwan University

minakerj@macewan.ca 